
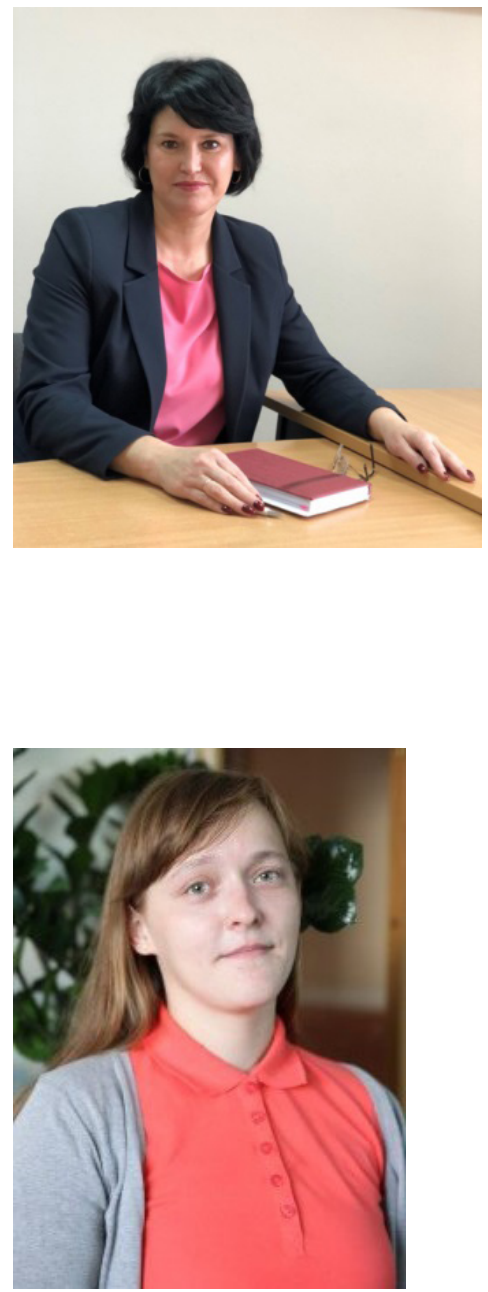

\section{Тетяна Федірчик,}

доктор педагогічних наук, професор, декан факультету педагогіки, психології та соціальної роботи, Чернівецький національний університет імені Юрія Федьковича

(м. Чернівці, Україна)

\section{Tatiana Fedirchyk,}

Doctor of Pedagogical Sciences, Professor, Dean of the Faculty of Pedagogy, Psychology and Social Work, Chernivtsi National Yuriy Fedkovich University (Chernivtsi, Ukraine) fedirchyktanya@gmail.com ORCID ID 0000-0002-5433-516X

\section{Віталія Дідух,} аспірант, Чернівецький національний університет імені Юрія Федьковича (м. Чернівці, Україна)

\author{
Vitaliia Didukh, \\ Postgraduate, \\ Chernivtsi National Yuriy Fedkovich University \\ (Chernivtsi, Ukraine) \\ vitaliadidukh@gmail.com \\ ORCID ID 0000-0001-6773-4736
}

\title{
ПЕДАГОГІКА ПАРТНЕРСТВА ЯК ЧИННИК ФОРМУВАННЯ ЕФЕКТИВНОЇ ВЗАЄМОДІЇ УЧАСНИКІВ ОСВІТНЬОГО ПРОЦЕСУ В УМОВАХ НОВОÏ УКРАÏНСЬКОÏ ШКОЛИ
}

Анотація. У статті розкрито сутність поняття «педагогіка партнерства», зазначено принципи та засади, на яких базується педагогіка партнерства, згідно з Концепцією «Нова українська школа», доведено доцільність дослідження цього напряму педагогіки.

Обґрунтовано педагогіку партнерства як чинник формування ефективної взаємодії учасників освітнього процесу на засадах педагогіки партнерства. Виокремлено види педагогіки партнерства, зокрема соціально-педагогічне партнерство, та розкрито його специфіку.

Представлено результати дослідження рівня готовності майбутніх учителів початкової школи до взаємодії 3 учасниками освітнього процесу на основі педагогіки партнерства.

Ключові слова: педагогіка партнерства, соціально-педагогічне партнерство, взаємодія, учасники освітнього процесу, демократичний підхід, гуманізація освіти.

\section{PEDAGOGY OF PARTNERSHIP AS A FACTOR OF FORMATION OF EFFECTIVE INTERACTION OF PARTICIPANTS OF THE EDUCATIONAL PROCESS IN THE CONDITIONS OF THE NEW UKRAINIAN SCHOOL}

Abstract. The article describes the essence of the concept of «partnership pedagogy», outlines the principles and principles on which partnership pedagogy is based on the Concept of the New Ukrainian School, and proves the necessity to study this line of pedagogy. Partnership pedagogy is substantiated as a component of the formation of the innovative educational space of the New Ukrainian School from a psychological and pedagogical standpoint. The results of the study of 
the level of willingness of future primary school teachers to interact with the participants of the educational process on the basis of partnership pedagogy are presented.

During the reforms and changes in the Ukrainian education, especially in elementary school, to optimize the learning process should take a look you on the interaction between the participants of the educational process in the light of new approaches that include: creating a favorable atmosphere of cooperation and collaboration; the transition from the practice of transferring teacher material that can be obtained from available sources and transition to active communication with students during educational activities; intensification of the introduction into the educational process of "active" teaching methods that are aimed at disclosing the individual, developing his initiative, motivation for cognitive activity, which is disclosed in the current normative documents of the education system, namely in the Law of Ukraine "On Education" and in the Concept "New Ukrainian School".

The analysis of the def and nition of the concept of "partnership" testifies to its multidimensionality. Partnership pedagogy is considered by scientists as a well-defined system of relationships between all participants in the educational process (students, educators, managers, parents), which is based on the principle of voluntariness, which is based on the respect and equality of all participants, while respecting certain norms (rights and obligations ) the benchmarks of each party; involves the active involvement of all participants in the implementation of common tasks and the willingness to take responsibility for their results. Thus, pedagogy of partnership acts as a factor of effective interaction of participants in the educational process in the New Ukrainian School, whose main purpose is to support students, which contributes to the development of their abilities, satisfies the intellectual, emotional and social needs of children, which meets the needs of modern educational theory .

Keywords: partnership pedagogy, social-pedagogical partnership, interaction, participants in the educational process, democratic approach, humanization of education.

\section{ВСТУП}

Постановка проблеми. У процесі реформування української освіти, зокрема початкової школи, для оптимізації навчального процесу необхідно поглянути на взаємодію між учасниками освітнього процесу крізь призму нових підходів, що передбачають: створення сприятливої атмосфери для співпраці; перехід від передачі педагогом матеріалу, який може бути одержаний із доступних джерел, та переходу до активного спілкування з учнями в процесі освітньої діяльності; інтенсифікацію впровадження в освітній процес «активних» методів навчання, які спрямовані на розкриття особистості, розвиток її ініціативності, мотивації до пізнавальної діяльності, що розкрито в чинних нормативних документах системи освіти, а саме: у Законі України «Про загальну середню освіту» та в Концепції «Нова українська школа».

Міністерством освіти та науки України спільно з ДНУ «Інститут освітньої аналітики» проведено дослідження умов реформування загальної середньої освіти на початку 2018-2019н.р. у контексті освітньої діяльності вчителів початкової школи, у процесі якого з'ясовано, що педагогіка партнерства $€$ одним із напрямів реформування загальної середньої освіти. На думку більшості респондентів (90,9\%), демократичний стиль взаємодії з учнями є найбільш ефективний.

Аналіз основних досліджень і публікацій. Проблема взаємодії між учасниками освітнього процесу на засадах педагогіки партнерства висвітлена у працях зарубіжних і вітчизняних учених. Так, у 60-70 роках XX століття P. Бенедикт, О. Больнов, Р. Лохнер, М. Мід, Б. Ананьєв, К. Корсак, В. Куліков здійснили наукові розвідки того чи іншого аспекту партнерства в контексті освітніх змін; В. Сухомлинський, О. Захаренко, Ш. Амонашвілі впроваджували появу зразків його практичного застосування в школі. Завдання гуманізації освіти полягає в реалізації демократичного підходу, який повинен опиратися не тільки на методологічні, а й аксіологічні основи партнерства. На це звертають увагу відомі українські дослідники гуманістичного навчання і виховання та проблем розвитку особистості (Д. Пащенко, В. Андрущенко, С. Гончаренко, І. Бех, І. Зязюн, В. Кузь, А. Хуторський, Л. Вовк, О. Савченко, Г. Балл, В. Сухомлинський, В. Кремень, В. Бондар, М. Ярмаченко).

З огляду на вимоги сучасності до вчителя та його взаємодії у процесі професійної діяльності, проблема педагогіки партнерства у взаємодії учасників освітнього процесу є актуальною та потребує ПОДАЛЬШИХ ДОСЛІДЖЕНЬ

\section{МЕТА І ЗАВДАННЯ ДОСЛІДЖЕННЯ}

Мета дослідження полягає у виявленні, розкритті та обґрунтуванні педагогіки партнерства як чинника формування ефективної взаємодії учасників освітнього процесу за умов Нової української школи з психологопедагогічної позиції та емпіричному дослідженні готовності майбутніх учителів початкової школи до реалізації взаємодії з учасниками освітнього процесу на її засадах.

\section{РЕЗУЛЬТАТИ ДОСЛІДЖЕННЯ}

Для розкриття сутності педагогіки партнерства з'ясуємо зміст поняття «партнерство», яке переважно визначається вченими:

- система взаємин, які відбуваються у процесі певної спільної діяльності (Бех І., 2017, с. 6);

- спосіб взаємодії і взаємин, організованих на принципах рівності, добровільності, рівнозначущості та доповнюваності всіх її учасників (Коломинський Я., 2007, с. 12);

- організаційна форма спільної діяльності, що передбачає об'єднання осіб на відповідних умовах розподілу праці та активної участі в її реалізації (Левківський М., 2016, с.8);

- спосіб взаємин, за яких зберігаються права кожної із сторін, чітко узгоджені і злагоджені дії учасників спільної справи, що ґрунтуються на засадах взаємовигоди та рівноправності (Бібік Н., 2018, с. 11).

Аналіз дефініцій поняття «партнерство» засвідчує багатоаспектність означеного поняття. На нашу думку, найбільш інтегрованим та цілісним тлумаченням означеного поняття $€$ визначення Н. Бібік, згідно з яким педагогіка 
партнерства - чітко визначена система взаємин усіх учасників освітнього процесу (учнів, батьків, учителів, управлінців), основою якої $є$ принцип добровільності; ґрунтується на повазі й рівноправності всіх учасників, дотримуючись визначених норм (прав та обов'язків) та враховуючи ціннісні орієнтири кожної із сторін; передбачає активне включення всіх учасників у реалізацію спільних завдань та готовність брати на себе відповідальність за їх результати.

Більшість учених (І. Бех, Н. Бібік, Г. Назаренко) вказують на те, що педагогіка партнерства базується на повазі до особистості; доброзичливості та позитивному ставлення; довірі у стосунках; принципі «діалог - взаємодія взаємоповага»; розподіленому лідерстві (проактивність, право вибору та відповідальність за нього, горизонтальність зв'язків); соціальному партнерстві (рівність сторін, добровільність взяття зобов'язань, обов'язковість виконання домовленостей) (Бех І., 2017, с.12).

Для сприяння самореалізації всіх школярів треба розуміти, що неповторною унікальністю є кожен учень. Таким чином, базовим принципом побудови освітнього середовища школи є пріоритет вільного розвитку особи, головна мета якого полягає в розумінні кожної особистості та виявленні до неї поваги.

Здійснюючи аналіз видів педагогіки партнерства, варто звернути увагу на соціально-педагогічне партнерство, яке нами (на основі аналізу поглядів учених) розглядається як окрема форма взаємодії освітнього закладу з певними юридичними чи фізичними особами, яка базується на засадах пріоритетної ролі закладу освіти під час реалізації його особистісно-розвивальної функції. Учасниками такого партнерства є сім'я, педагоги та керівництво освітнього закладу.

Основною метою соціального партнерства є залучення батьків до освітнього процесу школи шляхом створення необхідних умов, що сприятимуть залученню сім'ї до підтримки та супроводу дитини в закладі освіти.

О. Коханова визначає партнерство, яке полягає у: встановленні партнерських стосунків з сім'ями учнів; побудові гуманістичних орієнтирів та способів їх досягнення під час спільної діяльності; залученні батьків до організації освітнього процесу та управління житєєіяльністю школи; науково-методичному та інформаційному супроводі як педагогічного, так і психологічного навчання батьків, яке сприяє підвищенню їхньої компетентності; проведенні різноманітних діагностик, мета яких полягає у визначенні запитів та реалізації освітніх потреб як батьків, так і учнів.

Соціально-педагогічне партнерство як чітко визначена система взаємин усіх учасників освітнього процесу (батьків, учнів, учителів, керівників) повинна забезпечувати:

- на рівні сім'ї (створення стимулюючої духовної та морально-психологічної атмосфери; оволодіння необхідним обсягом психолого-педагогічних знань; інтеґрацію зі школою);

- на рівні діяльності педагога (стимулювання до творчого пошуку, уміння бачити проблеми та засоби їх розв'язання; пріоритет взаємин співробітництва, співтворчості; модернізація форм, методів навчання та виховання);

- на рівні діяльності керівництва закладів освіти (добір педагогічних працівників відповідного рівня, здатних сприяти розвитку учнів; забезпечення умов для самостійної діяльності педагогів, підвищення їх загальнокультурного та професійного рівня).

Не менш важливим при реалізації педагогіки партнерства $€$ врахування її психологічної основи, яку становлять суб'єкт-суб'єктні стосунки - співпраця як мінімум двох суб'єктів (учителі - батьки, учителі - учні, учителі управлінці, батьки - управлінці, батьки - учні, управлінці - учні). Цей тип взаємин для освітнього процесу є найбільш оптимальним, бо дає можливість учневі діяти самостійно, однак інші учасники освітнього процесу діють разом та займають тьюторську позицію. Тому завдання педагогів, батьків та керівників полягає у створенні атмосфери, яка б сприяла розвитку можливостей учнів, задовольняла їхні інтелектуальні, емоційні та соціальні потреби. На нашу думку, найбільш вагомим у процесі реалізації педагогіки партнерства є таке:

- по-перше, особистісно зорієнтований підхід, суть якого полягає у взаємодії вчителя із дитиною на основі великої любові і поваги до неї. Такий шлях пропонували В. Сухомлинський та Ш. Амонашвілі. Проте не всі учні вірять у свою «рівність» з учителем, але й педагоги не готові до такого стилю стосунків;

- по-друге, партнерський підхід, при реалізації якого здійснюється розподіл функцій між учасниками освітнього процесу і організація їхньої співпраці.

Наприклад, до завдань учителя належить ретельно підготувати для дитини навчальне завдання чи задачу, продумати хід його виконання в деталях, ураховуючи індивідуальні особливості учня. Завдання учня на добровільних засадах прийняти завдання, яке запропонував учитель, як своє і самостійно ї̈ виконати. У такому випадку обоє учасників освітнього процесу, учитель і учень, рівноправні, вони є суб'єктами діяльності: учитель не застосовує владу, так реалізується ідея рівності. Але не кожен учитель має достатній запас любові до дітей, проте кожен може побудувати навчання так, щоб дитина почувала себе істотою вільною і час від часу забувала, що в класі є «спостерігач»;

- по-третє, підхід, що сприяє самореалізації кожного учня; взаємодія вчителів, батьків та менеджерів освіти повинна бути спрямована на те, щоб кожний учень зміг розвинути здібності критичного мислення і незалежного висловлювання; поповнити знання у сферах, які передовсім цікаві учневі й розкривають перед ним нові шляхи пізнання; розвинути спроможність самостійно ухвалювати рішення; оволодіти необхідними навичками з базових та профільних предметів; навчитися радіти навчанню та поважати освіту; зміг розвинути свій емоційний інтелект; отримати необхідну індивідуальну педагогічну підтримку; зберегти і зміцнити моральне, фізичне і психічне здоров'я тощо. Робота з учнями будується на використанні в навчанні нових підходів, які переносять акцент не на накопичення знань, а на формування технологій розумової праці учнів та уміння застосовувати знання на практиці;

- по-четверте, створення ситуації успіху, яка полягає у співпраці вчителя і учнів, партнерстві на уроці, спільному процесі пізнання і відкриття.

Дослідниця О. Коханова виокремлює критерії, що визначають ефективність ідеї розвитку стосунків партнерства як найпродуктивнішої системи відповідних умов педагогічної взаємодії: 
- сформована професійно-особистісна готовність педагога до гуманізації освітнього середовища;

- відкритість, тобто практично повна відсутність маніпуляцій за умови ясності цілей дій обох сторін;

- позитивна взаємозалежність суб'єктів міжособистісної взаємодії (усвідомлення спільної мети, наявність загальних ресурсів, докладання спільних зусиль для розв'язання проблем);

- право на автентичність кожного учасника педагогічної взаємодії;

- усвідомлення індивідуальної та групової відповідальності (внутрішня і зовнішня мотивація спільної діяльності суб'єктів);

- можливість задовольняти основні міжособистісні потреби в процесі спільної діяльності та спілкування;

- підтримуюча взаємодія, що забезпечує сприятливий психологічний клімат взаємодії; високий рівень розвитку соціальних умінь і навичок спілкування; рефлексивний аналіз власної поведінки в контексті соціальної поведінки інших суб'єктів.

Уважаємо, що урахування зазначених критеріїв $є$ необхідною умовою створення сприятливих партнерських взаємин між учасниками освітнього процесу та допоможе керівництву закладу освіти, працівникам психологічної служби у визначенні заходів як організаційних, так і просвітницьких щодо підвищення психологічної компетентності учасникам освітнього процесу з питань упровадження партнерських взаємин. Готовність учителів початкової школи до взаємодії з учасниками освітнього процесу на засадах педагогіки партнерства передбачає сформованість у них: ставлення та спрямованість учителів до використання педагогіки партнерства в професійній діяльності в процесі налагодження педагогічної взаємодії; знань про сутність та основні принципи педагогіки партнерства як педагогічної технології; уміння використовувати форми, методи організації взаємодії з учасниками освітнього процесу на засадах педагогіки партнерства.

Нами було проведено констатувальне дослідження на базі Чернівецького національного університету імені Юрія Федьковича, кафедри педагогіки та методики початкової освіти. Респондентами у процесі дослідження стали студенти 4-6 курсів спеціальності «Початкова освіта» у кількості 135 здобувачів вищої освіти, які уже засвоїли більшу частину теоретичного матеріалу та пройшли основні види навчальних практик. Це дослідження складалося із трьох блоків. Перший блок мав на меті виявити рівень розуміння зазначеного поняття та принципи, на яких ґрунтується педагогіка партнерства.

За результатами опитування встановлено, що тільки 30\% респондентів розуміють правильно і точно поняття «педагогіка партнерства» і лише 20\% усвідомлюють значення принципів, на яких ґрунтується педагогіка партнерства (див рис.1).

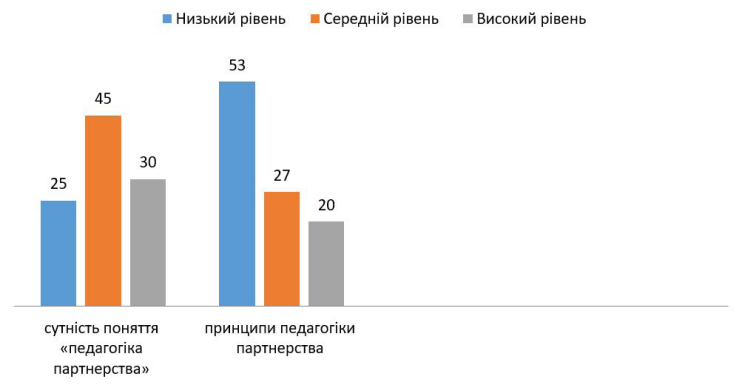

Рис. 1. Результати опитування студентів щодо розуміння ними сутності поняття «педагогіка партнерства» та принципів педагогіки партнерства

Запитання другого блоку дали змогу з'ясувати думку студентів про важливість використання педагогіки партнерства та ї̈ вплив на ефективність освітнього процесу. Результати засвідчили (див. рис. 2): більшість (64\%) респондентів вважає, що використання педагогіки партнерства є важливим та еФективним в освітньому процесі початкової школи.

" важлива/ефективна = частково важлива/ефективна

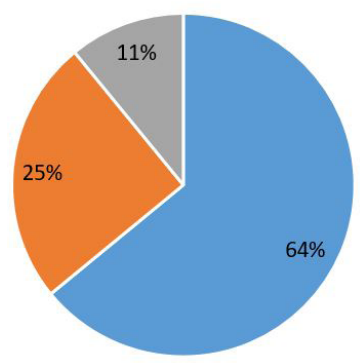

Рис. 2. Результати опитування студентів про важливість використання педагогіки партнерства та ї̈ вплив на ефективність освітнього процесу 
Третій блок запитань спрямований на визначення самооцінки рівня володіння студентами формами і методами педагогіки партнерства (рис. 3).

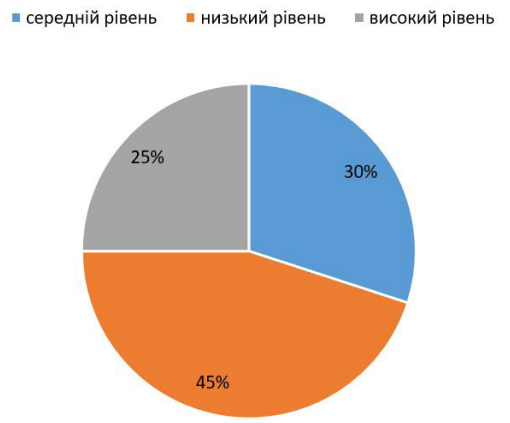

Рис. 3. Результати визначення самооцінки рівня володіння студентами формами і методами педагогіки партнерства

Аналізуючи ці результати, дійшли висновку, що тільки у 25\% здобувачів вищої школи на високому рівні самооцінка рівня володіння формами і методами педагогіки партнерства.

\section{ВИСНОВКИ ТА ПЕРСПЕКТИВИ ПОДАЛЬШИХ ДОСЛІДЖЕНЬ}

Педагогіка партнерства є важливим чинником ефективної взаємодії учасників освітнього процесу за умов Нової української школи, головною метою якої є підтримка учнів, яка сприяє розвитку їхніх можливостей, задовольняє інтелектуальні, емоційні й соціальні потреби дітей, що відповідає запитам сучасної освітньої теорії та практики.

Здійснюючи аналіз результатів констатувального дослідження, ми з'ясували, що система підготовки здобувачів вищої освіти до професійної діяльності потребує вдосконалення, зокрема щодо використання студентами форм, методів та прийомів педагогіки партнерства, мета яких полягає у встановленні ефективної взаємодії з учасниками освітнього процесу (учителями, учнями, батьками, керівництвом та адміністрацією школи), на що будуть спрямовані подальші дослідження.

\section{СПИСОК ВИКОРИСТАНИХ ДЖЕРЕЛ}

Бех, І. (2018). Компонентна технологія сходження зростаючої особистості до духовних цінностей. Початкова школа, 1, 5-10. Бібік, Н. (Ред.). (2018). Нова українська школа: порадник для вчителя. Київ: Літера лтД. Закон України Про освіту. №36-39 розд. II ст. 12. (2017). Відомості Верховної Ради. № 38-39, ст.380.

Зязюн, І. (2012). Аналіз педагогічної дії у площині самовизначення вчителя. Креативна педагогіка. Наук.-метод. журнал, 6,11-18. Коломинский, Я. (Ред.). (2007). Психология педагогического взаимодействия. Учебное пособие. Санкт-Петербург: Речь. Коханова, О. (2011). Психологія партнерської взаємодії в освіті: навчально-методичний посібник. Київ: ПП Щербатих О. Левківський, М. (2016). Історія педагогіки: підручник. Київ: Центр навчальної літератури.

Яланська, С. (2015). Психологія розвитку педагогічної творчості: Навчальний посібник. Полтава : ПНПУ імені В.Г. Короленка.

\section{REFERENCES}

Beh, I. (2018). Component technology convergence of a growing personality to spiritual values. Primary school, 1, 5-10.

Bibik, N. (ed.). (2018). The New Ukrainian School: A Teacher's Guide. Kyiv: Literature LTD.

Zyazyun, I. (2012). Analysis of the pedagogical action in the plane of self-value of the teacher. Creative pedagogy. Scientific method. Magazine, 6 , 11-18.

Colomina, I. (Ed.). (2007). Psychology of pedagogical interaction. Tutorial. SPb.: Speech.

Kohanova, O. (2011). Psychology of partner interaction in education: educational and methodical manual. Kyiv: PP Shcherbatykh O.

Levkovskii, M. (2016). The history of pedagogy: textbook. Kiev: Center for Educational Literature.

Yalanska, S. (2015). Psychology of Pedagogical Creativity Development: A Manual. Poltava: PNPU named after V.G. Korolenko. 